\title{
Production Management Model in Small and Medium Enterprises in Croatia
}

\section{Model upravljanja proizvodnjom u malim i srednjim poduzećima u Hrvatskoj}

\author{
Original scientific paper • Izvorni znanstveni rad \\ Received-prispjelo: 6. 6. 2017. \\ Accepted-prihvaćeno: 23. 5. 2018. \\ UDK: $630 * 79$ \\ doi:10.5552/drind.2018.1805
}

\begin{abstract}
Small and medium enterprises play a key role in the economy of the European Union as the main generators of employment and economic development. According to the official statistics of the EU, about 99.8 $\%$ of enterprises are small and medium. In order to be successful, the company needs to harmonize various parameters through strategic planning, preparation, organization and decision making. For the purpose of the research, two questionnaires were used, one for the purposes of descriptive statistics and $\chi^{2}$ test, and the other for the purpose of AHP data analysis. The $\chi^{2-}$ test shows the opinion of surveyed experts and company managers, while the AHP method demonstrates the parameters considered most and least important for the company business. In contrast to the environmentally friendly production, which has shown to have the least significant impact on the management system, the market, promotion and marketing have the most significant impact. According to the results, production and business management model and block diagram were established.
\end{abstract}

Key words: small and medium enterprises, production and business management, block diagram, management model, parameters of effectiveness

SAŽETAK • Mala i srednja poduzeća kao osnovni generatori zapošljavanja i gospodarskog razvoja imaju ključnu ulogu u gospodarstvu EU-a. Prema službenoj statistici Unije, oko 99, 8 \% poduzeća čine upravo mala i srednja poduzeća. Za uspješno poslovanje poduzeća potrebno je uskladiti brojne parametre koji se ostvaruju strateškim planiranjem, pripremom, organizacijom i donošenjem odluka. U radu su primijenjena dva anketna upitnika, jedan za potrebe deskriptivne statistike $i \chi^{2}$-testa, a drugi za potrebe AHP analize podataka. Testom $\chi^{2}$ prikazana su razmišljanja anketiranih eksperata i menadžera poduzeća, dok je AHP metodom ustanovljeno koji su parametri najvažniji za poslovanje poduzeća, a koji su manje važni. Najveći utjecaj na sustav upravljanja imaju tržište, promocija i marketing, a najmanji utjecaj ima ekološki čista proizvodnja. Na osnovi dobivenih rezultata uspostavljen je model upravljanja proizvodnjom i poslovanjem te izrađen blok-dijagram.

Ključne riječi: mala i srednja poduzeća, upravljanje proizvodnjom i poslovanjem, blok-dijagram, model upravljanja, parametri učinkovitosti

\footnotetext{
${ }^{1}$ The author is a doctor of science in wood tecnology. ${ }^{2}$ The author is a professor at the Faculty of Forestry,University of Zagreb, Croatia.

${ }^{1}$ Autor je doktor biotehničkih znanosti u polju drvne tehnologije. ${ }^{2}$ Autor je profesor Šumarskog fakulteta Sveučilišta u Zagrebu, Hrvatska.
} 


\section{INTRODUCTION}

\section{UVOD}

Today, micro, small and medium enterprises account for the majority of jobs. In addition, they provide a significant source of entrepreneurial spirit and innovation. Furthermore, there are approximately 23 million small and medium enterprises in the European Union. 75 million work posts account for $99.8 \%$ of all enterprises (Jelačić et al., 2015).

According to the Small Business Development Promotion Act, entrepreneurs are classified by size into three categories, i.e. micro, small and medium enterprises. Micro enterprises are those that employ less than 10 workers and generate less than EUR 2.000,000 in operating revenues per year. On average, small entrepreneurs employ less than 50 workers p.a. and generate less than EUR 10.000,000 in operating revenues per year. In contrast, medium enterprises are those that employ more than 50 and less than 250 workers and generate a total annual turnover of more than EUR 10.000,000 (Ukić and Kuran, 2015).

Managing such companies is a continuous process that drives and directs business activity in order to achieve its goal. This type of business deals with issues such as financing, which is reflected in the inability to access the capital necessary for its establishment and development (OECD, 2016). The development of both the economy and enterprise is valued through management systems that, along with a certain number of people, business plans and financial flows, must be aligned with other factors in the production process in order to survive. Difficulty in managing small and medium enterprises stems from the inability to conduct a comprehensive market research. A small business owner must personally perform all essential managerial functions, and must deal with administrative issues (obtain work permits, deal with taxes and insurance, abide by the Act on Employment, Dismissal, Revision, etc.) (Bennett, 1994).

The management structure in the wood-processing sector (micro, small and medium enterprises) is reduced to a low level of knowledge and awareness of the benefits of the production management systems. The lack of standardized management systems that incorporate risk analysis tools, reduction of business risks and an array of other internationally-recognized management systems can have a significant negative impact on the business and life cycle of organizations, regardless of their size, structure or form of ownership (Britvić, 2011).

The support provided to businesses and SMEs development makes the structure of envisaged and coordinated activities and measures undertaken by different entities at different levels of decision making (Ren et al., 2015). Such a system requires efficient institutions or experts who are well familiar with entrepreneurship, business and development specific for this type of enterprise. Today, successful business operations and the development of small and medium enterprises require a quality solution to the problems related to their own technological and product development (Okolić, 2007).

The production itself needs to be well prepared and precisely planned, so that all jobs can be performed in a timely fashion, including the optimal consumption of all productive resources: materials, labor, money, information, instrumentation and energy (Grladinović et al., 2007).

Compared to large companies, small and medium enterprises have limited resources and little impact on the market (Kivijärvi and Tuominen, 1996). Their survival depends on the ability to get the most out of available resources and quickly find the market niche and adapt to it in an appropriate manner. Therefore, a rapid response to changes is considered the key to survival of SMEs (Zhang et al., 2009).

Innovation can be seen as a solution to the company's survival. For example, market share of more innovative companies tends to increase in volume, in contrast to the underperforming companies whose failure forces them to search for innovation opportunities. Consequently, the companies that base their progress on innovativeness stand a better chance of having higher export values (Pirc-Barčić and Motik, 2013).

The aim of this research was to present the current situation in small and medium enterprises and to propose a more efficient management system. The basic data was obtained by e-mail and phone calls. The collected data was analyzed by descriptive statistics, $\chi^{2-t e s t}$ and AHP method. The establishment and proposal of the new model is based on the results obtained and previously published separately.

\section{MATERIALS AND METHODS} 2. MATERIJALI I METODE

For the purpose of this research, a survey questionnaire was distributed to 130 micro, small and medium wood processing and furniture manufacturing companies in 4 countries from the South East European region (Croatia, Macedonia, Serbia and Slovenia). Out of the total number of questionnaires, 117 were distributed to micro and small enterprises, and 13 questionnaires to medium enterprises. The questionnaire was sent to most companies via email, while some companies sent their responses by phone, through direct interview or by mail (Dillman, 2000). Out of 130 companies in total, only 30 , and all of them from Croatia, responded to the distributed questionnaires and their responses were analyzed at a later stage. The research method consisted of collecting the data on the parameters of effectiveness of the production management system in small and medium businesses. Two questionnaires were produced. The first was used to describe descriptive statistics and perform the $\chi^{2-t e s t,}$ while the other was used to implement the Analytical Hierarchy Process (AHP). The first questionnaire was divided into two parts. The first part contained general data about the company. The first group of questions (1-11) was posed directly to the owners or managers of the company. The second group consisted of 29 ques- 
tions about the production management system parameters (12-40) measured by Liker four-level scale, and these were answered by the owners (managers) of the company as well as by external experts from the same 4 countries in South East European region (Croatia, Macedonia, Serbia and Slovenia), who were not employed in the companies, but whose responses were needed for the $\chi^{2}$ test and the AHP method in order to compare the answers received by the company. These questions were posed in order to get the opinions of the company owners and external experts. The goal of such a survey response collection process was to determine the differences in responses between business managers and eternal experts. Additionally, a separate questionnaire that had been produced for the AHP method was filled out by experts to obtain the seven parameters and a certain set of relations between the parameters as a basis to compute the AHP. These seven parameters were obtained by assessing the importance of questions (alternatives) in the second part of the questionnaire (12-40). Excel and Word were used for the first survey questionnaire, and a free AHP online software (http://bpmsg.com/) for the second questionnaire.

The $\chi^{2}$-test determines whether there is a relationship between the two variables and thus shows the probability of the relationship between them. The $\chi^{2-}$ test was run on the group of questions 12-40. The aim of the above test was to show which questions were statistically very significant, significant, or not statistically significant at all (Grubišić, 2004).

Analytical Hierarchy process or shorter AHP is one of multi-criteria decision making tools that have

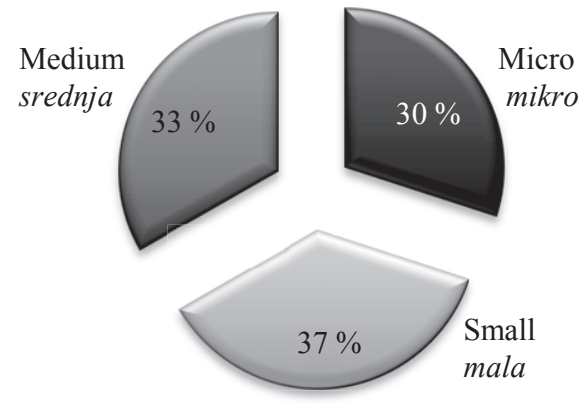

Figure 1 Type of business

Slika 1. Vrsta poduzeća been used in decision making to help decision makers choose the best decision among several alternatives (Motik at al., 2010). In this paper, the AHP method was used to rank the performance parameters that affect the production management system in small and medium businesses. If Consistency Ratio $(\mathrm{CR}) \leq 0.10$ for a matrix $\mathrm{A}$, then the estimates of relative importance of criteria are considered acceptable. In the opposite case, it has to be investigated why inconsistency of estimates is unacceptably high. Therefore, the assessed relative importance of the estimates of the matrix A in our example is not sufficiently consistent. It is necessary to improve the consistency of the assessment so that the $\mathrm{CR} \leq 0.10$ requirement is met (Lisjak, 2011).

\section{RESULTS AND DISCUSSION}

\section{REZULTATI I RASPRAVA}

The first group of questions (1-11) provides general company-related information provided directly by managers or business owners. Figures (1-6) demonstrate the basic results pertaining to the surveyed companies such as the type of company, their legal form, markets, manufacturing processes, equipment in terms of machinery and the production program.

The second part of the questionnaire consisted of questions related to production management system parameters (12-40). These 29 questions were divided into 7 major groups, which consequently were the parameters for AHP analysis of the production and business management system. The results of the $\chi^{2}$-test



Figure 3 Production management organization Slika 3. Organizacija upravljanja proizvodnjom

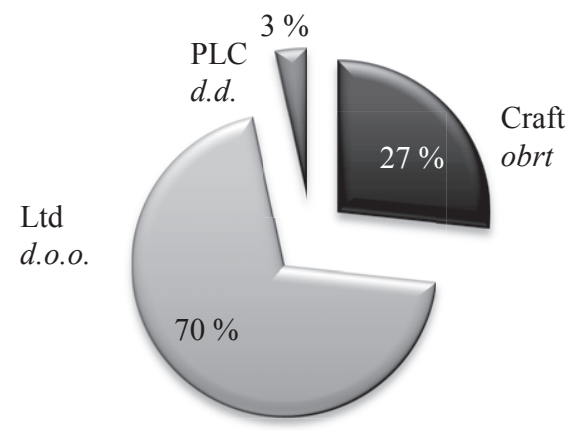

Figure 2 Legal forms of companies Slika 2. Pravni oblici poduzeća

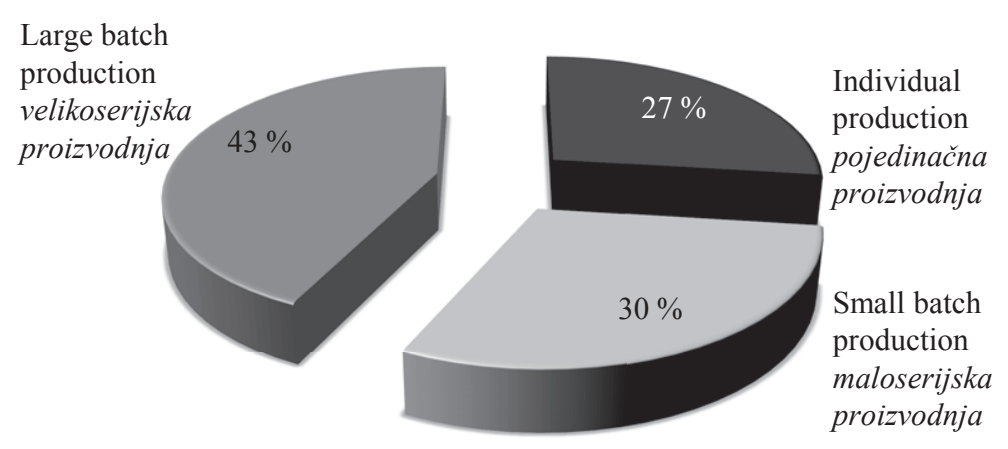

Figure 4 Production processes

Slika 4. Proizvodni procesi 


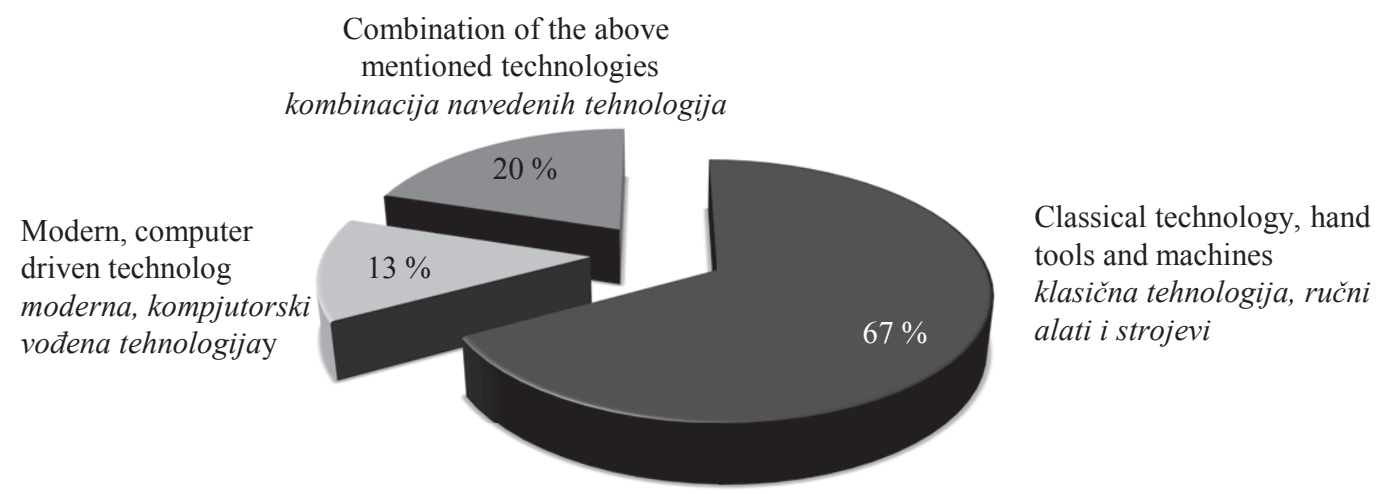

Figure 5 Equipment in terms of machinery Slika 5. Opremljenost poduzeća strojevima

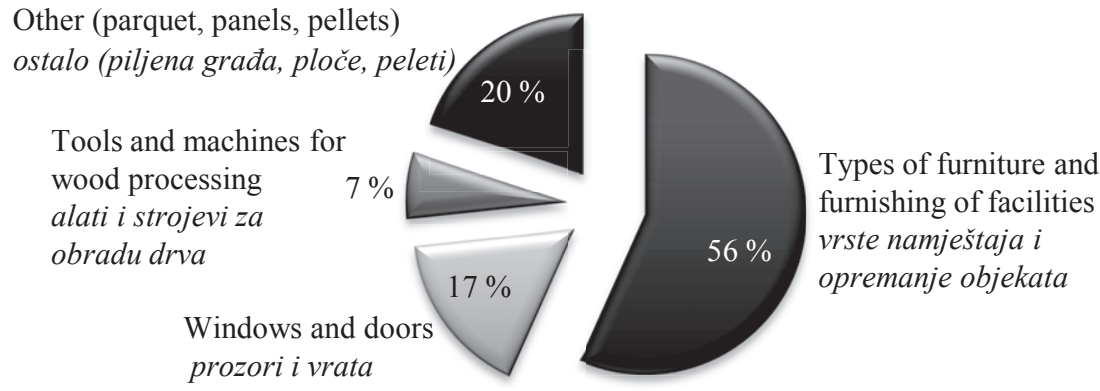

Figure 6 Production program of the company

Slika 6. Proizvodni program poduzeća

were previously published separately (Dušak et al., 2017), but as they were the basis for this research they will be explained here.

The questions from the questionnaire, 29 of them, with 135 statements all together, were divided into 7 groups: VPOSP - Leadership, Policy, and Organizational Structure of the Company; PKUPRP - Process Culture, Management Processes, and Production Deadlines; PPKP - Range of Products and Quality of Products; TPM - Marketing and Market Activities of the Company; LJP - Human Resources; ITSPT - Information Technology and Modern Production Technology; EČP - Environmentally friendly production. Those groups were used for AHP analysis afterwards.

Answers from managers and external experts on each question and each statement were placed into relationship according to $\chi^{2}$-test requirements to establish the differences in opinions between managers who deal with these problems within the companies and external experts who deal with these issues as external consultants for the companies.

The $\chi^{2}$-test was conducted as the Pearson's Chi Square with obtained P values: $p<=0.001$ - the differences are statistically very highly significant (99.9\%), $0.001<p<=0.01-$ the differences are highly significant $(99.0 \%), 0.01<p<=0.05-$ the differences are significant $(95.0 \%), p>0.05$ - the difference is not statistically significant $(90.0 \%)$.

According to the results obtained in the research, all of the $\mathrm{P}$ values showed that there was a highly or very highly significant difference between answers given by managers and by external experts to each individual statement in each individual question in the questionnaire. A very highly significant difference was found in several statements of the questions, such as organized work posts, work conditions, personal sales, higher product quality, quality management system and lean production system.

To be able to help managers to make a quality decision about problems that occur in their production and business management systems, it was necessary to establish which process of the production and business management system should be taken care of the most, and which management parameter to pay the most attention to. Therefore, the AHP analysis was performed.

As mentioned earlier, for the purposes of AHP method, the second questionnaire was developed. It consisted of 7 groups of parameters, mentioned above, placed in pairs of direct relationship to each other. The same external experts, as in $\chi^{2}$-test analysis, were asked to answer the AHP questionnaire. The AHP analysis was conducted on each of the answered questionnaire, the Consistency Ratio (CR) was checked, and those questionnaires where $\mathrm{CR}$ was higher than $10 \%$ were considered non-consistent and they were excluded from the research. Therefore, 6 out of 10 questionnaires were taken into consideration and put into overall AHP analysis presented in Figure 7 (Dušak et al., 2017).

Figure 7 shows that the parameters, ranked according to the AHP method starting from the most important parameters or factors to those that are considered least important, indicate that the market, promotion and marketing have the most significant impact on the production management system in small and medium businesses $(24.9 \%)$, followed by the production program and product quality (19.6\%), information tech- 

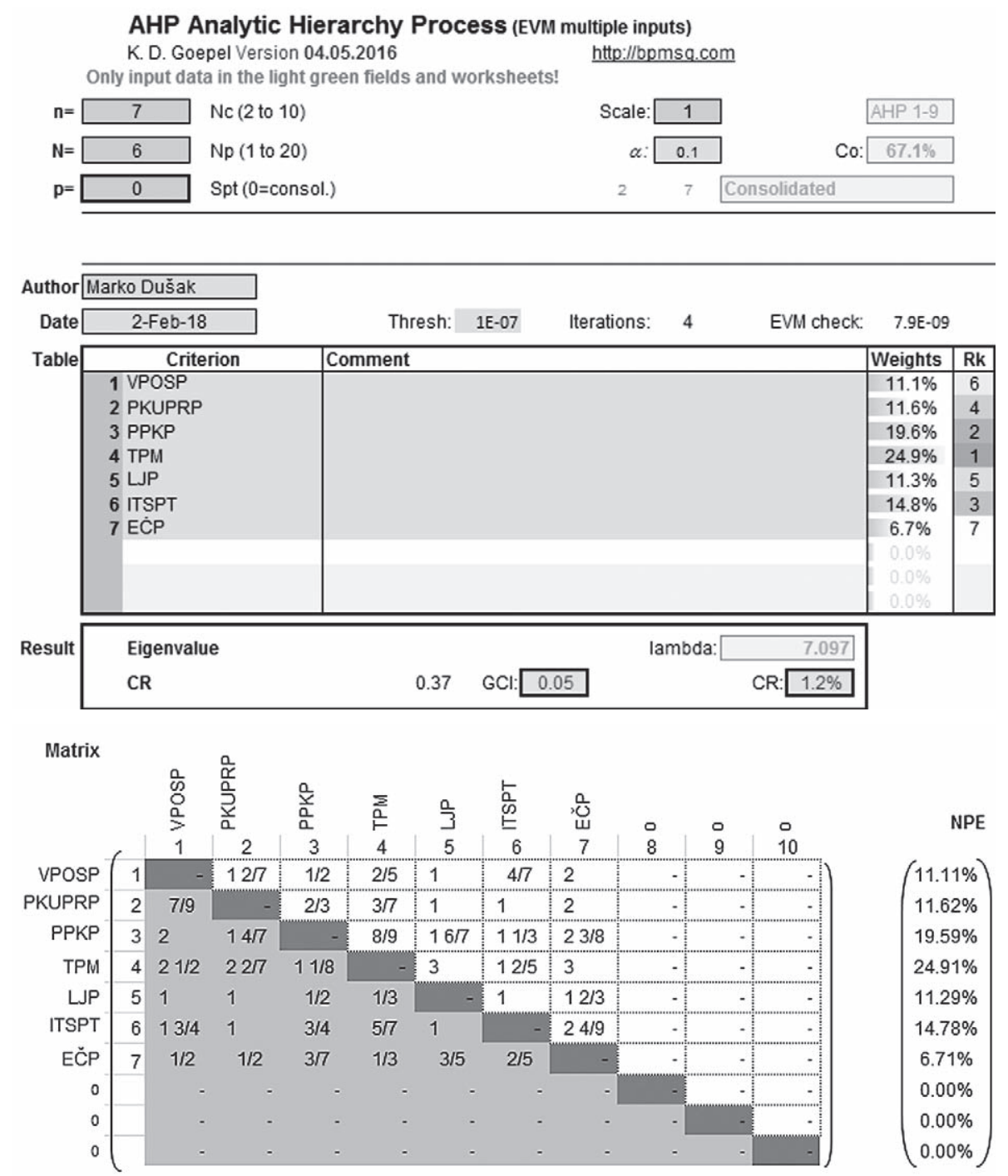

Figure 7 Results of AHP analysis - consolidated data

Slika 7. Rezultati AHP analize - konsolidirani podaci

VPOSP - Leadership, Policy, and Organizational Structure of the Company / vodstvo, politika i organizacijska struktura poduzeća; PKUPRP - Process Culture, Management Processes, and Production Deadlines / procesna kultura, upravljački procesi i rokovi proizvodnje; PPKP - Range of Products and Quality of Products / proizvodni program i kvaliteta proizvoda; TPM - Marketing and Market Activities of the Company / tržište, promocija i marketing; LJP - Human Resources / ljudski potencijali; ITSPT - Information Technology and Modern Production Technology / informacijska tehnologija, suvremena proizvodna tehnologija; EČP - Environmentally friendly production / ekološki prihvatljiva proizvodnja; Nc - Number of criteria $(2-10)$ / broj kriterija $(2-10)$; $N p$ - Number of participants $(1-20)$ / broj ispitanika $(1-20)$; Selected participant $(0=$ consolidated) / izabrani ispitanik ( 0 = ukupan); Co - Consensus / ugovorena vrijednost (67,1\%); CR - Consistency ratio / omjer konzistencije; GCI - Geometric consistency index / indeks geometrijske konzistencije; NPE - Normalized principal Eigenvector / normalizirani glavni svojstveni vektor

nology and modern production technology (14.8\%), the process culture, management processes and production deadlines $(11.6 \%)$, human resources $(11.3 \%)$, leadership, policy and organizational structure of the company $(11.1 \%)$, and environmentally friendly production as the least important $(6.7 \%)$.

The block diagram shows the order of decision making activities when entering the market (Figure 8). The model uses the stated goal (the new product) with the seven parameters of effectiveness to demonstrate the profitability of innovation in the new product development. If all the answers were positive, then the innovation, production program, production technolo- gy, management system, human resources, organizational structure and production ecology would give the innovative product the boost to enter the market. Quite the opposite, if all the answers were negative, the product would remain as it is. Some innovations do not require a positive answer to all statements. Innovation in a product that does not require the change in production technology or in human resources, is still an innovation on a smaller scale, not a radical one, and it can still bring some good results and benefits to the market. The same statement stands for each innovation on a smaller scale that can result in a better position on the market and bring benefits to the company. 


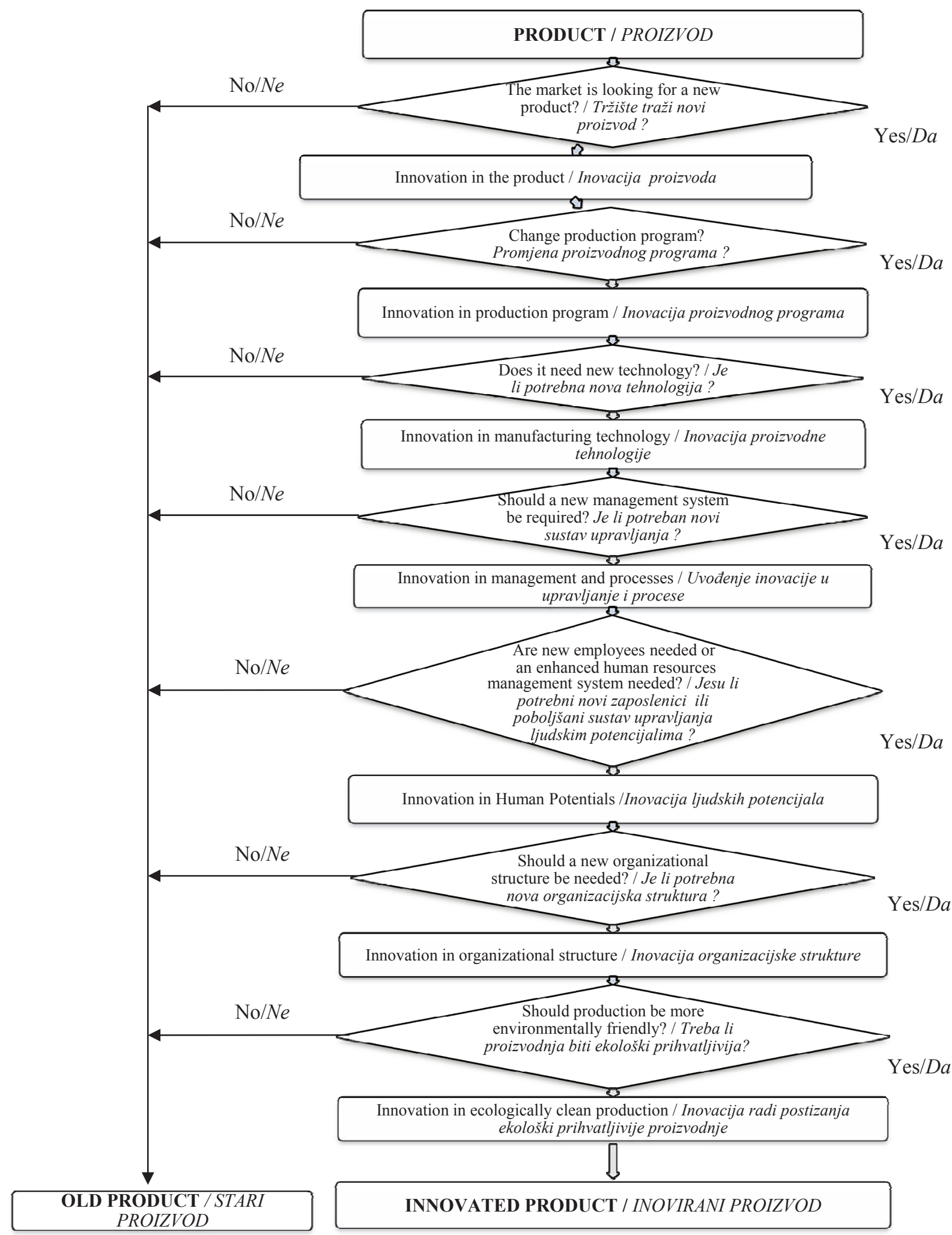

Figure 8 Block diagram of the order of activities in decision making in small and medium businesses Slika 8. Blok-dijagram redoslijeda aktivnosti pri donošenju odluka u malim i srednjim poduzećima

According to the developed block diagram, it was necessary to establish the organization model for small and medium enterprises (Figure 9) that could help make the decision process in a company easier and faster and meet the requirements of the turbulent and ever-changing market for wood products and furniture.

The newly established model was developed based on AHP analysis and block diagram and it meets the requirements of the market classified in 7 groups of production and business management parameters. Each group consists of parameters the company should think of when entering the market and it was a part of the first questionnaire, which was the basis for this research (Dušak et al., 2017). Usually, the organization models place different functions or group of parameters of the same of similar importance on the same 
....... Dušak, Jelačić: Production Management Model in Small and Medium Enterprises...

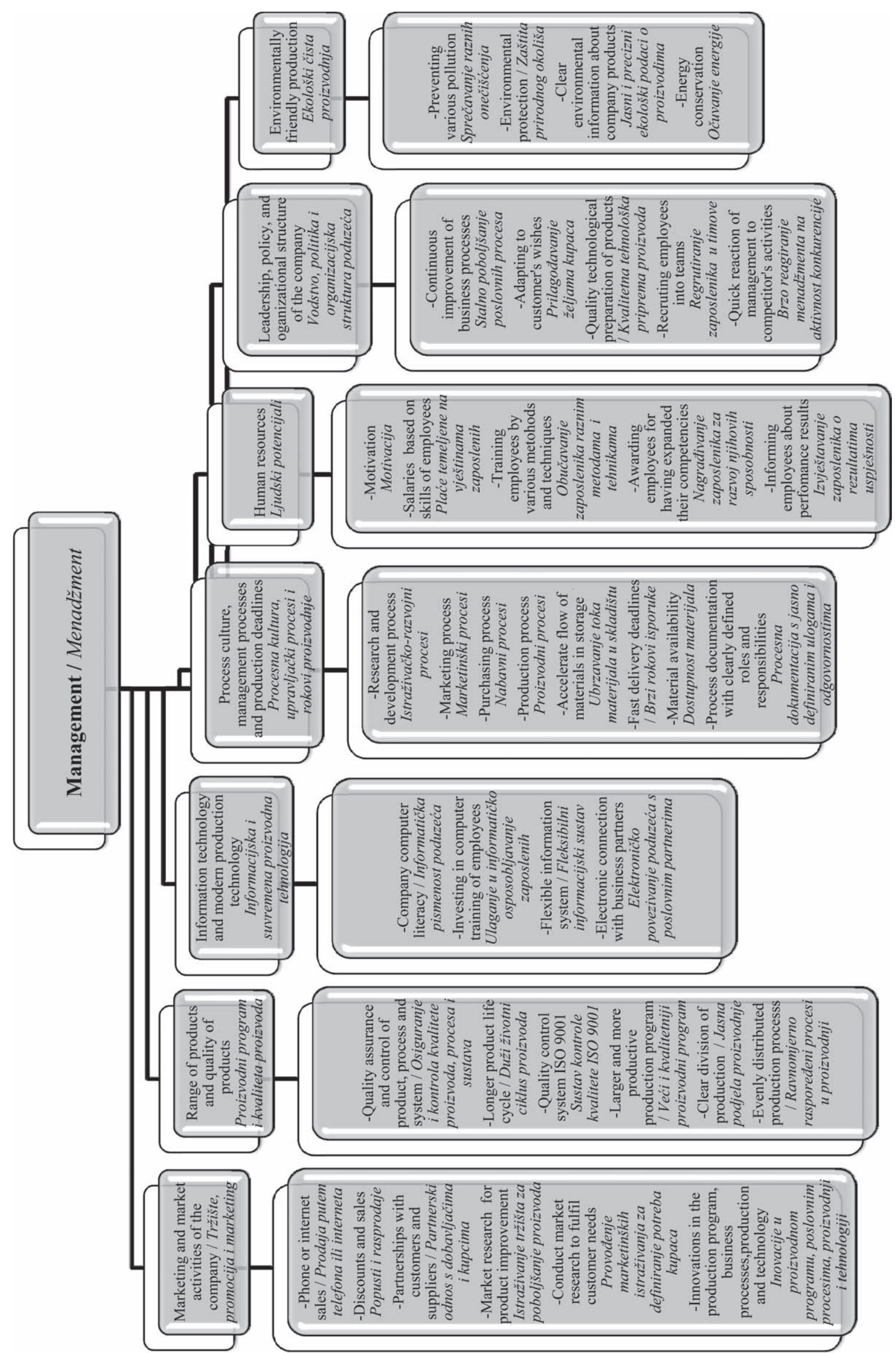

Figure 9 Organization model in small and medium businesses

Slika 9. Organizacijski model u malim i srednjim poduzećima 
level. The groups of parameters in this model are almost at the same level and they are almost equally important in decision making process, but some of the parameters or groups of parameters, according to AHP analysis, have slightly higher priority. Therefore, they are not at exactly the same level, but slightly moved up or down according to priority they achieved in the analysis.

The model is flexible and if the company management decides to go into the innovations in information technology or in human resources, it could bring a specific group of parameters up front in the model and make the decision making process easier, faster and more effective.

Also, small and medium companies usually do not have enough staff to deal with all these issues at the same time and discuss them during weekly meetings or otherwise. That is especially relevant to small and micro companies, where one or two persons have to make decisions on all issues. Therefore, they need some kind of model that will give priorities to some issues and make the whole decision making process easier and faster.

\section{CONCLUSION}

\section{ZAKLJUČAK}

The presented data indicate that the small and medium enterprises provide an above-average contribution to the business economy in Croatia.

The aim of this research was to present the current situation of small and medium companies in the wood industry in Croatia, and show possible solutions to various problems in the production management systems.

The AHP method demonstrated the order of effectiveness parameters of the production management system, and revealed, based on expert opinion, which factor in the production process should be dealt with more attention and which with less. The model itself showed the cost-effectiveness of innovation related to certain factors with the purpose of obtaining a new product. The company cannot be characterized as creative and innovative by itself. This requires internal organization and external environment as the foundation for innovative action, and the above-mentioned responses within the model show exactly that.

Further to the above, this research is important because it represents the structure of an improved production management in small and medium businesses. The results of the surveyed companies and experts indicate the current situation in the surveyed companies in Croatia. Apart from the lack of staff, information and modern production technology, the companies have also not been receiving enough incentives from the state, government or various agencies. Therefore, based on the presented models, the decision making process in small and medium enterprises can be easier, faster and more efficient. These models are the tools for small and medium enterprises to be more innovative and to respond more promptly to market requirements.

\section{REFERENCES}

\section{LITERATURA}

1. Bennett, R., 1994: Management. Potecon, pp. 54-70.

2. Britvić J., 2011: Moderni sustavi upravljanja u organizacijama. Praktični menadžment, Stručni časopis za teoriju i praksu menadžmenta, 2 (1): 72-80.

3. Dillman, D. A., 2000: Mail and Internet Surveys - the Tailored Design Method. John Wiley \& Sons, Inc., New York, NY.

4. Dušak, M.; Jelačić, D.; Pirc-Barčić, A.; Novakova, R., 2017: Improvements to the Production Management System of Wood-processing in Small and Medium Enterprises in Southeast Europe. Bioresources, 12 (2): 33033315. https://doi.org/10.15376/biores.12.2.3303-3315

5. Grladinović, T.; Kropivšek, J.; Oblak, L., 2007: Modern production and business management in wood processing and furniture manufacture. Drvna industrija, 58 (2): 77-87.

6. Grubišić, A., 2004: Hi-kvadrat i njegove primjene. Seminarski rad. Sveučilište u Zagrebu, Fakultet elektrotehnike i računarstva, Zagreb.

7. Jelačić, D.; Šatanova, A.; Sedliačikova, M.; Zavadsky, J.; Zavadska, Z., 2015: Process Model of Quality Cost Monitoring for Small and Medium Wood-Processing Enterprises. Drvna industrija, 66 (4): 329-338. https://doi.org/10.5552/drind.2015.1437

8. Kivijärvi, H.; Tuominen, M., 1996: A decision aid in strategic planning and analysis of a wood-processing company. Computers and Industrial Engineering, 31(1-2): 467-470. https://doi.org/10.1016/0360-8352(96)00176-3

9. Lisjak, D., 2011: Primjena AHP metode kao alata za optimalni izbor opreme. Predavanje. Hrvatsko društvo održavatelja (HDO), Zagreb.

10. Motik, D.; Šegotić, K.; Jazbec, A., 2010: Application of AHP model and survey results in deciding on a product line in furniture industry. Drvna industrija, 61(2): 83-87.

11. OECD, 2016: Financing SMEs and Entrepreneurs 2016: An OECD Scoreboard. OECD Publishing, Paris. https://doi.org/10.1787/fin sme_ent-2016-en

12. Okolić, M., 2007: Sistem za podršku razvoja malih i srednjih poduzeća. Diplomski rad, Fakultet poslovne ekonomije, Banja Luka.

13. Pirc-Barčić, A.; Motik, D., 2013: Innovation and Innovativeness in Medium-Low Tech/Low-Tech Industries Wood Industry. Drvna industrija, 64 (3): 247-255. https://doi.org/10.5552/drind.2013.1301

14. Ren, S.; Eisingerich, A. B.; Tsai, H. T., 2015: How do marketing, research, and development capabilities, and degree of internationalization synergistically affect the innovation performance of small and medium-sized enterprises (SMEs)? A panel data study of Chinese SMEs. International Business Review, 24 (4): 642-651. https://doi.org/10.1016/j.ibusrev.2014.11.006

15. Ukić, Lj.; Martić Kuran, L., 2015: Uloga i značaj malih i srednjih poduzetnika na ruralnim područjima Dalmatinske zagore. Zbornik radova Veleučilišta u Šibeniku, 1-2.

16. Zhang, J.; Li, H.; Ziegelmayer, J. L., 2009: Resource or capability? A dissection of SMEs it infrastructure flexibility and its relationship with it responsiveness. The Journal of Computer Information Systems, 50 (1): 46-53.

\section{Corresponding address:}

MARKO DUŠAK, Ph. D.

Promid, Ltd., Nikole Tesle 32

Križevci, 48260, CROATIA

e-mail: marko-dusak1@hotmail.com 